\title{
Assessment and bioeconomic analysis of the Majorca (NW Mediterranean) trammel net fishery
}

\author{
Gorka Merino $^{1, \mathrm{a}}$, Beatriz Morales-Nin ${ }^{2}$, Francesc Maynou ${ }^{1}$ and Antoni Maria Grau ${ }^{3}$ \\ Institut de Ciències del Mar (ICM-CSIC), Passeig Marítim de la Barceloneta 37-49, 08003 Barcelona, Spain \\ 2 Institut Mediterrani d'Estudis Avançats (IMEDEA-CSIC-UIB), Miquel Marquès 21, 07190 Esporles, Illes Balears, Spain \\ 3 Dirección General de Pesca del Govern de las Illes Balears, Foners 10, 07006 Palma de Mallorca, Illes Balears, Spain
}

Received 15 January 2008; Accepted 10 April 2008

\begin{abstract}
Trammel net is the main fishing gear used by artisanal fishers in Majorca Island (NW Mediterranean), and is representative of Mediterranean small-scale fisheries using static gear. The use of static gears close to the coast, where seasonal variability and spatial heterogeneity are high, promotes the diversification of fishing practices or metiers. We analyze the seasonal dynamics of the nets used, target species (red and black scorpionfish, red mullet and cuttlefish) exploitation patterns and the socio-economic conditions under which this fishery takes place, based on General Fisheries Directorate daily sale records (2002-2006). Additional personal socioeconomic interviews allowed the characterization of the trammel net fishery, its fishing behaviour, cost structure and conflicts. Catch and effort data and market surveys are used to evaluate the level of exploitation of the target species and allowed describing Majorca trammel net fishery as an activity based on a sustainable resource. The main target species were found to be near their maximum sustainable yield both by means of a surplus production model (with parameters estimated by CEDA-Catch Effort Data Analysis, software) and an age structured assessment model based on yield-per-recruit analysis. Management actions currently debated by local administration and fishers focus on improving fishers' economic situation, rather than on protecting a threatened resource. One of the management actions proposed is a one day effort reduction, which was analyzed here with the help of a bioeconomic simulation model. A 15-year (2005-2020) simulation allows providing advice to local managers to focus on the commercialization aspects, in order to obtain a higher value to the fish production, rather than expecting to obtain higher profits only by a reduction of the offer.
\end{abstract}

Key words: Small-scale fisheries / Socioeconomics / Bioeconomic Simulation / Assessment

Résumé - Estimation et analyse bio-économique d'une pêche au trémail de l'île de Majorque (NO Méditerranée). Le filet trémail est le principal engin de la pêche artisanale utilisé par les pêcheurs de l'île de Majorque (NO Méditerranée); il est représentatif de la petite pêche en Méditerranée, utilisant des engins dormants. L'usage de ces engins dormants à proximité de la côte, où la variabilité saisonnière et l'hétérogénéité spatiale sont élevées, entraîne la diversification des pratiques de pêche ou métiers. Nous analysons la dynamique saisonnière des filets utilisés, les espèces-cibles (rascasse rouge, rascasse blanche, le mulet barbet et la seiche), les modèles d'exploitation et les conditions socio-économiques sous lesquelles la pêcherie se développe, basées sur les données des ventes journalières de la Direction Générale des Pêches (2002-2006). Des enquêtes socio-économiques ont permis de caractériser la pêcherie au trémail, les comportements de pêche, la structure des coûts et les conflits. Les données d'effort et de capture et l'étude du marché sont utilisées pour évaluer le niveau d'exploitation des espèces-cibles et permettent de décrire la pêcherie au trémail de Majorque comme une activité basée sur des ressources à l'équilibre. Les principales espèces-cibles sont trouvées proches de leur rendement maximum à l'équilibre, à la fois au moyen d'un modèle de surplus de production (avec des paramètres estimés au moyen du logiciel CEDA, Catch Effort Data Analysis) et par un modèle d'estimation structurée en âge, basé sur l'analyse des rendements par recrue. La gestion couramment débattue par l'administration locale et les pêcheurs se focalisait sur l'amélioration de la situation économique des pêcheurs plutôt que de protéger une ressource en danger. Une des actions de gestion proposée est une réduction de l'effort - un jour de pêche, qui peut être analysée ici avec l'aide d'un modèle de simulation bio-économique. Une simulation sur 15 ans (2005-2020) permet de fournir des conseils aux gestionnaires locaux sur les aspects de commercialisation, en vue d'obtenir une plus

\footnotetext{
a Corresponding author: gmerino@icm.csic.es
} 
haute valeur de production de poissons, plutôt que d'espérer obtenir des profits plus élevés par une réduction de l'offre seulement.

\section{Introduction}

Globally, the importance of small scale fisheries is based on the fact that they contribute to a half of the fish consumed by humans (FAO 2003; Stergiou et al. 2006). It is well-known that Mediterranean artisanal fisheries are predominantly multi-species, multi-fleet and multi-metier fisheries, with a high socioeconomic and cultural importance on their fishing communities. Small-scale fishing is associated to coastal waters (Colloca et al. 2004). Small scale demersal fisheries in Mediterranean waters include over 100 very appreciated species of fish, crustacean and mollusks (Lleonart and Maynou 2003).

Artisanal fisheries have been previously described for some European Mediterranean regions (Martorell and Oliver 1986; Sanchez et al. 2000; Guillou et al. 2002; Colloca et al. 2004; Garcia-Rodirguez et al. 2006; Stergiou et al. 2006; Tzanatos et al. 2006), but a comprehensive assessment of their exploitation status is lacking, due to the difficulty in sampling this type of fisheries and because the activities of the Stock Assessment Sub-Committee of the General Fishery Commission for the Mediterranean (SAC, GFCM: the organization responsible for regional biological assessment of resources) are mainly focused to large-scale, semi-industrial trawl and purse seine fisheries (Lleonart and Maynou 2003). Available data limits the opportunities to use age- and length-based methods (Lleonart and Maynou 2003; Stergiou et al. 1997), although life history parameters (e.g. length-weight relationships, age-length keys) are available for various fish stocks (Morey et al. 2003). As a result, the collection of data and assessment of stock status have been traditionally performed within the framework of scientific projects, with no continuity over time, as required for assessment purposes, and have rarely been performed for the small-scale fisheries (Lleonart and Maynou 2003). Therefore, the actual state of resources has not been specifically evaluated for most artisanal fisheries and may vary among species and areas.

The first of the objectives of this work is to describe the Majorca Island trammel net fishery (multi-species and multigear), both in biological and economic terms. The artisanal fishery includes 496 boats in the Balearic islands and 164 in Majorca. Trammel nets are used by around 138 of the boats in Majorca, targeting a large pool of commercial species or categories. The Administration considers that there is no fleet overcapacity based on the reduction of the fleet to $50 \%$ in the last 20 years and the diminution of landings by only $25 \%$ (A.M. Grau unpubl. data). The boats employed in this fishery correspond to group $\mathrm{C}$ (minor gear with engine), as defined by the SAC of the CGFM. The usual fishing practice is to rotate target species and fishing gears depending on season and species availability (Iglesias et al. 1995).

There are three main trammel nets in use according to the regulation in the Balearic Islands. These differ in mesh size and hence in mean length of the catch: Cuttlefish trammel net, red mullet trammel net and spiny lobster trammel net. Red mullet trammel net operates over sand-Posidonia interface at
30-35 m, cuttlefish trammel net over mixed bottoms from 2$30 \mathrm{~m}$ and lobster net on maerl or coralligen bottoms between 70-100 m deep. The first two are the subject of the current analysis, while the spiny lobster fishery, which operates in deeper waters, is not taken into account.

There is no management or assessment of these artisanal fisheries besides the effort control which is regulated by the D.G. Pesca after EU regulation. Mediterranean regulation imposes limits to the fishing activities through restrictions to the number of licenses expended, number of fishing days and hours permitted and fishing gears. The fishery is regulated by two administrations, inner waters by the autonomous.

Government, and open waters by the Fisheries Directorate. The regulation of trammel nets was fixed in Balearic Islands in 2003 as follows: the mesh size of the external nets must be $220 \mathrm{~mm}$, while the internal is $67 \mathrm{~mm}$. Red mullet can be fished by gill nets or trammel nets, but the net or inner net must be of $50 \mathrm{~mm}$. Lobster trammel net inner net must be of $133 \mathrm{~mm}$. The maximum net length allowed is $2000 \mathrm{~m}$ per fisher with a maximum of $6000 \mathrm{~m}$ per boat. Only one artisanal gear can be used in a fishing day. The maximum number of hours at sea each day is 16 , with a weekly stop of 30 h. No fishing with trammel net is allowed deeper than $60 \mathrm{~m}$, except from AprilAugust for lobster.

The social and economic aspects of the fishery were investigated through socioeconomic interviews to vessel owners operating trammel net in Majorca Island.

The socioeconomic characterization of the Majorca Island trammel net fishery was made according to fishing behaviour, fishing tactics, regulation preferences and complaints of the Majorca trammel net fleet with interviews in the main harbours of the island (Alcúdia, coord. 39.51N- 3.23E, Cala Ratjada, 39.7 N-3.42 E Colònia de Sant Jordi, 39.19 N- 2.59 E, Palma, 39.35 N- 2.39 E, Pollença, 39.88 N-3.02 E and Porto Colom 39.43 N- 3.25 E). The answers, jointly with the recommendations of the fishery manager (D.G. Pesca) were used for the second main objective of the present work: to simulate both fisheries sustainability and the impact of a hypothetical management measure, on a bioeconomic model specifically designed for the simulation of Mediterranean small-scale fisheries, MEFISTO (Mediterranean Fisheries Simulation Tools) software (Lleonart et al. 2003). Bioeconomic simulation models allow forecasting the biological and economic effects of alternative management strategies (Merino et al. 2007).

MEFISTO software (Lleonart et al. 2003) is used here to test the effects of a one day effort reduction to the trammel net fleets activity on fishers' profits. At the time of the design of our scenario, the one day effort reduction was perceived by fishers as a way to increase the average price of the product in the local markets (fishers' pers. comm.). MEFISTO simulation model was used with a price formation function including offer-demand, based on market surveys. Finally, the increase in prices needed to equalize current profits ("break-even" ratio) was investigated. 


\section{Material and methods}

\subsection{The data}

Different data sources were used to address both the biologic and socioeconomic description of the Majorca island trammel net fishery. The exploitation state of the main four target species of the fleet was estimated by means of official daily landings and price data series from 2002 to 2006 provided by the General Fisheries Directorate and the Spanish Oceanographic Institute. Catch-at-age analysis was made with catch-length and price records from market surveys in 2006.

In addition, 27 personal socioeconomic interviews in the main harbours of the island (Alcúdia, Cala Ratjada, Colònia de Sant Jordi, Palma, Pollença and Porto Colom) were used to describe technical characteristics, cost structure, fishing tactics and to evaluate management proposals of the trammel net fleet. The 27 interviews represent approximately $20 \%$ of the total trammel net fleet estimated to be of 138 operative vessels.

Fishers were contacted in advance and met in their own harbours. The questionnaires were filled in by the authors reporting fishers' answers and suggestions in real time, there was no additional correction and the answers were classified into a pool of possible answers. Once at the laboratory, answers were analyzed through simple statistics. Focus was placed on geographical differences and general coincidences.

The 22 questions in the questionnaires were divided in four main groups. First, questions about length, gross tonnage and crew allow the technical description of an average trammel net vessel. Second, questions about seasonal changes in target species, accompanying species and nets used allow the description of trammel net activity along the year. Seasonal differences in landings composition and nets used were observed. Third, socioeconomic aspects such as hours at sea and in the harbour, fuel consumption and cost structure, maintenance, number of nets renewed, equipment and investments were used not only to characterize average vessels but to run the bioeconomic simulation model. Fourth, questions about commercialization and complaints about management allowed the design of the scenario for the simulation of alternative management actions, such as a one day effort reduction and to highlight specific problems associated to particular geographical areas.

\subsection{Stock evaluation}

The biological parameters of a surplus production model, based on Schaefer's model (1954), were estimated for the 4 main species from catch and efort data series aggregated at a yearly scale. The software used for parameter estimation was CEDA 3.0 (Kirkwood et al. 2001). Results showing biomass level, catch fit and a projection into Schaefer's equilibrium curve allow a first attempt to assess the four species exploitation level.

The evaluation with the Schaefer's model (dynamic) was used for a further comparison with the cohort analysis (equilibrium) on one hand and to illustrate the level of exploitation of cuttlefish, which, as explained below, was impossible with the cohort analysis. No numeric value from the biomass dynamic model was used for the age structured analysis initialization.
Cuttlefish (Sepia officinalis) was left out of the cohort analysis due to problems in the fitting of growth parameters in cephalopods to von Bertalanffy growth function (Dunn 1999; Royer et al. 2006). The results of yield per recruit and VPA for red mullet, black and red scorpionfish using the VIT software (Lleonart and Salat 1992) helped estimate the exploitation patterns of the main species and initial population sizes, which were also used to initialize the bioeconomic simulation.

\subsection{The bioeconomic simulation model}

Techniques for the projection of biological and economic indicators to be examined over time have been developed in recent years to evaluate alternative management strategies of fisheries (Punt 1992; Ulrich et al. 2002; Griffin 2003; Lleonart et al. 2003; Merino et al. 2007).

MEFISTO simulation model has previously been used for transboundary fisheries analysis (Lleonart et al. 2003), fleets interactions (Merino et al. 2007) in the European Mediterranean and, in the present case, it is used for the analysis of two trammel nets activities (métiers) sharing the exploitation of two species (red mullet and red scorpionfish).

The model includes the possibility of testing the effects of removing vessels from a fishery or reducing their fishing time. The model comprises three submodels: the stock box, the market box and the fisher (or decision box). First, it simulates the population dynamics of target and accessory species with a classical age-structured model (Schnute 1985); second a price formation equation including imports, offer and size allows estimating the price of each cohort or age class and third a decision box simulates fishers' strategies such as investments, removal or increasing fishing effort. The equations can be revised in previous publications (Lleonart et al. 2003; Merino et al. 2007). The decision box, includes a pool of endogenous variables to describe individual fishers' behaviour. Increasing profits leads to increasing fishing effort until the maximum number of days permitted, while decreasing profits leads to reducing costs of fishing, getting into debt and finally dismissing fishing units. Fisher investments and continuous technological improvements are represented with a constant increase in catchability.

\section{Results}

Majorca trammel net fleet exploits four main species which yearly represent approximately $81.2 \mathrm{t}$ and $863 \mathrm{k} €$ (Fig. 1) of revenues: red scorpionfish (Scorpaena scrofa) represented $377 \mathrm{k} €$ in 2005, red mullet (Mullus surmuletus) represented $185 \mathrm{k} €$, cuttlefish (Sepia officinalis) represented $253 \mathrm{k} €$ and black scorpionfish (Scorpaena porcus) $48 \mathrm{k} €$ (based on official data by the General Fisheries Directorate provided by the daily sales registers on the only fishing wharf in the Island).

Yearly catch and effort series were constructed aggregating daily data and they were fitted to a global surplus production model (Schaefer 1954), with the parameters estimated using CEDA 3.0 software (Kirkwood et al. 2001) (Table 1). The simulation of species population and past yield, their fit to the real 

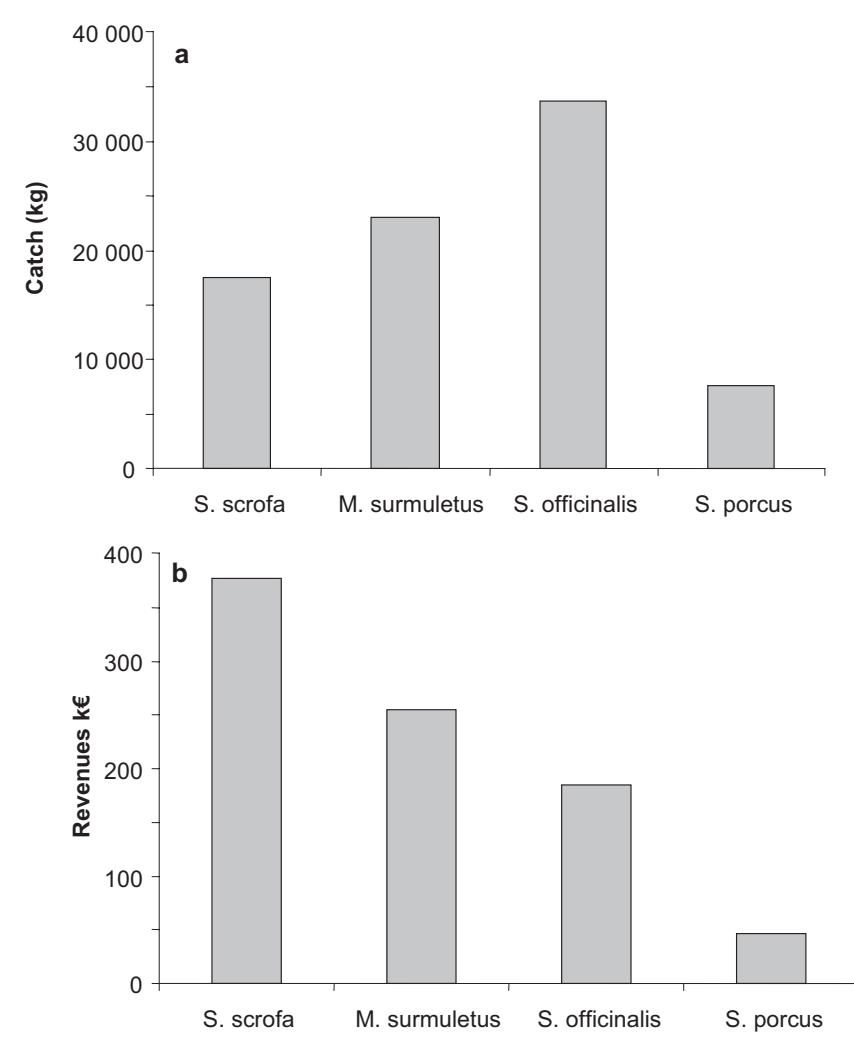

Fig. 1. Trammel net fisheries catch (a) and revenues (b) from the main target species (Red scorpionfish S. scrofa, red mullet $M$. surmuletus, cuttlefish $S$. officinalis and black scorpionfish $S$. porcus) in 2006 (based on official data by the General Fisheries Directorate).

Table 1. Four species Schaefer's model's parameters: $r$, intrinsic growth rate; $K$, carrying capacity; $B_{0}$, initial biomass in 2000; and $q$, catchability coefficient and $R^{2}$ between observed and estimated catch.

\begin{tabular}{lccccc}
\hline Fish species & $\begin{array}{c}r \\
\left(\mathrm{year}^{-1}\right)\end{array}$ & $\begin{array}{c}K \\
(\mathrm{~kg})\end{array}$ & $\begin{array}{c}B_{0} \\
(\mathrm{~kg})\end{array}$ & $\begin{array}{c}q \\
\left(\times 10^{-5} \text { days }^{-1}\right)\end{array}$ & $\begin{array}{c}R^{2} \\
R^{2}\end{array}$ \\
\hline S. scrofa & 0.9 & 84398 & 42199 & 8.4 & 0.92 \\
M. surmuletus & 3.9 & 24064 & 12452 & 2.5 & 0.87 \\
S. officinalis & 2.8 & 51640 & 25820 & 5.4 & 0.61 \\
S. porcus & 0.2 & 74143 & 37072 & 4.2 & 0.68 \\
\hline
\end{tabular}

*Average of the season. Includes $50 \mathrm{~mm}$ and $67 \mathrm{~mm}$ nets.

data and a projection into Schafer's equilibrium curve of the four species are shown (Figs. 2, 3, 4 and 5).

The global surplus models allowed us to assess each species exploitation level. The results showed that some species are at levels near the maximum sustainable yield (MSY) (red scorpionfish, red mullet and cuttlefish), while black scorpionfish would suffer, increasing fishing pressure setting its path far from Schaefer's equilibrium curve. For the first three, our results indicate absence of overfishing, while for black scorpionfish the increasing fishing effort indicates possible resource depletion.

A yield per recruit analysis was conducted based on total production and catch-length data from in situ surveys at local markets (Fig. 6) with the VIT software (Lleonart and Salat 1992). Table 2 shows von Bertalanffy length-weight and
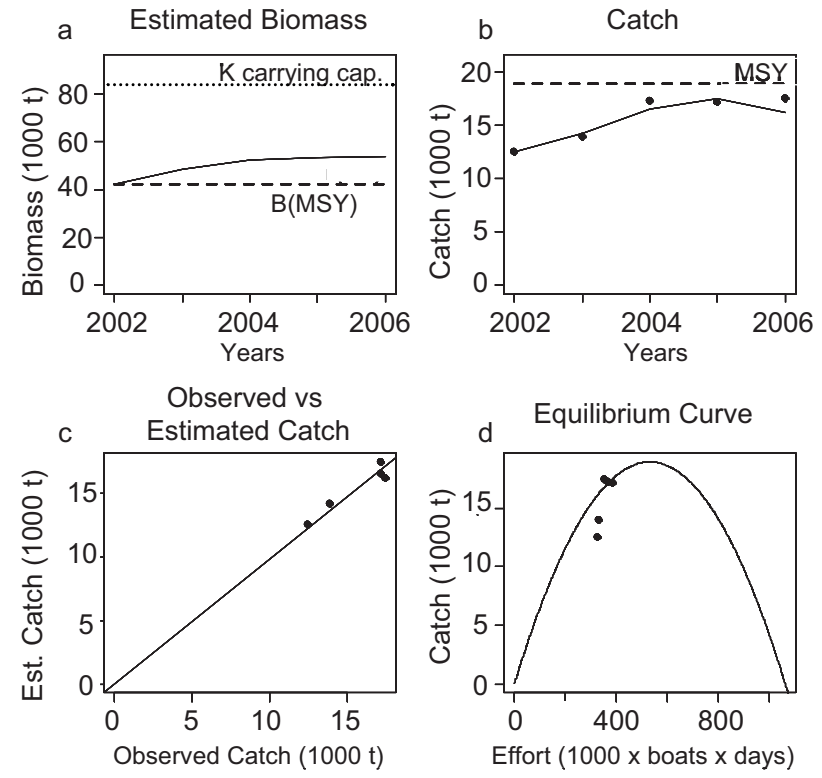

Fig. 2. Red scorpionfish (S. scrofa) estimated biomass, carrying capacity and MSY biomass level (a), MSY production, estimated and observed catch (b, c), observed catch projected to the Schafer's equilibrium curve (d).
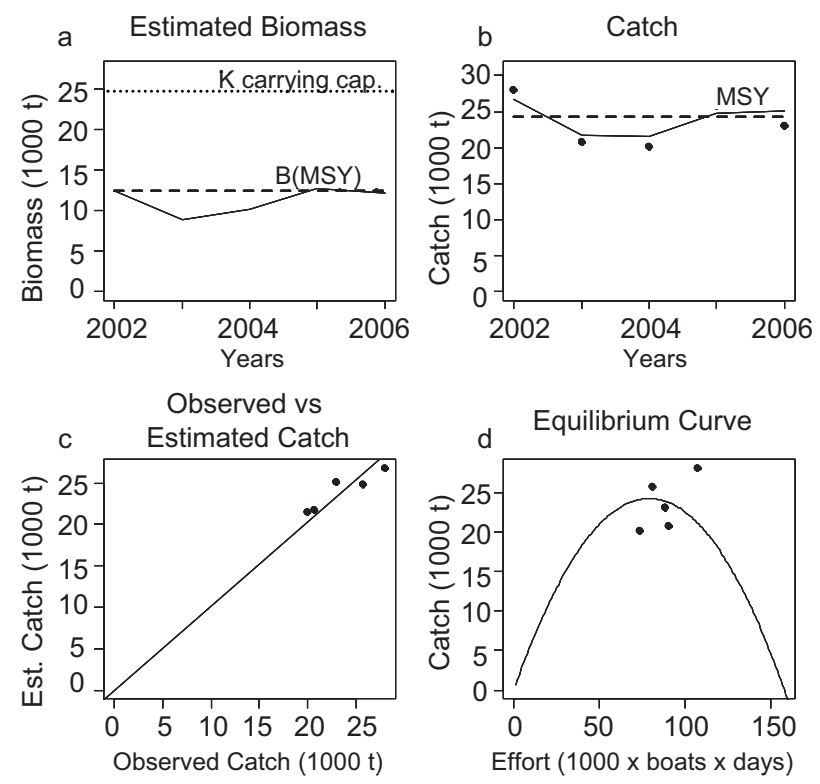

Fig. 3. Red mullet (M. surmuletus) estimated biomass, carrying capacity and MSY biomass level (a), MSY production, estimated and observed catch (b, c), observed catch projected to the Schafer's equilibrium curve (d).

length-age parameters for the yield per recruit analysis (Morey et al. 2003; Forsythe et al. 2002; Morales-Nin 2001).

Yield per recruit analysis do not indicate growth overexploitation in none of the three species shown. According to these results and the previous assessment based on Schafer's production model, the Majorca trammel net fisheries activity relies on a sustainable resource at safe levels, except in 

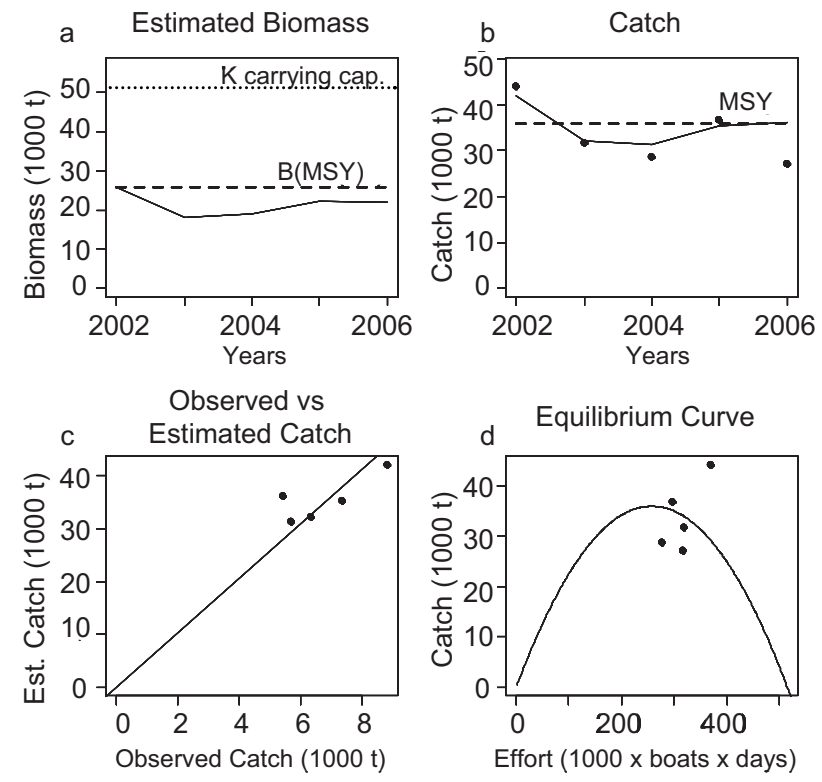

Fig. 4. Cuttlefish (S. officinalis) estimated biomass, carrying capacity and MSY biomass level (a), MSY production, estimated and observed catch $(b, c)$, observed catch projected to the Schafer's equilibrium curve (d).
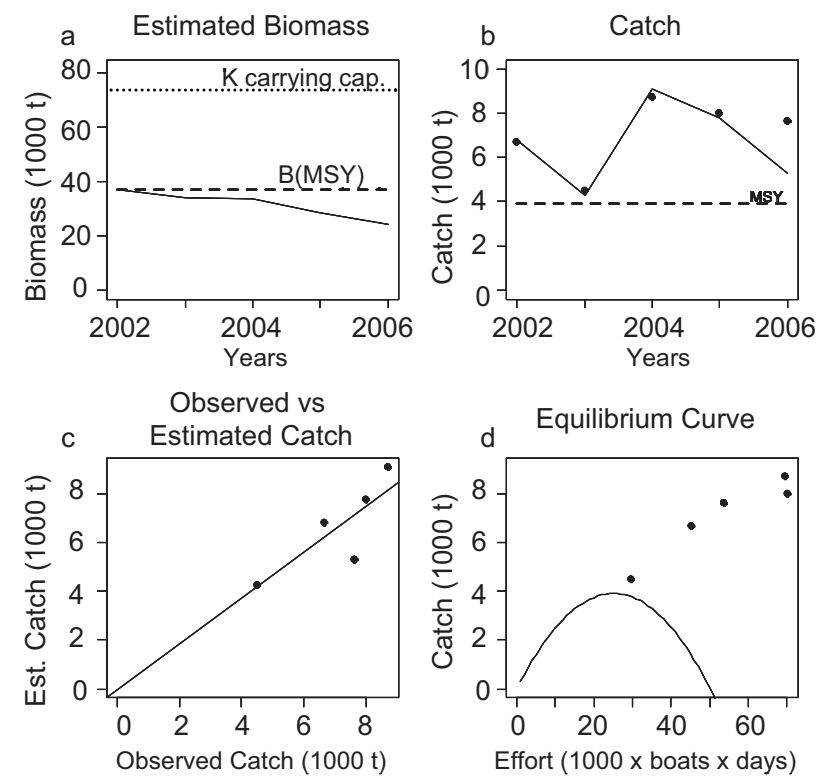

Fig. 5. Black scorpionfish (Sc. porcus) estimated biomass, carrying capacity and MSY biomass level (a), MSY production, estimated and observed catch (b, c), observed catch projected to the Schafer's equilibrium curve (d).

the case of black scorpionfish, caught often with the cuttlefish net, mainly small and medium individuals (as explained in the next section), suffering increasing overfishing. Revenues from black scorpionfish represent the $6.6 \%$ of the total revenues from the four target species.

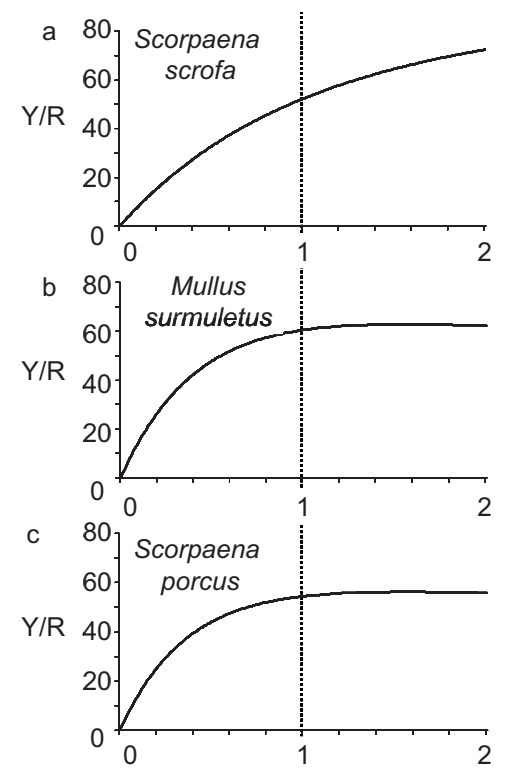

Fig. 6. Red scorpionfish (a), red mullet (b) and black scorpionfish (c) yield per recruit analysis.

Table 2. Species parameters: $a$ and $b$ are length-weight relationship parameters, $L_{\infty}, K$ and $t_{0}$ von Bertalanffy growth model parameters (Morey et al. 2003; Forsythe et al. 2002; Morales-Nin 2001).

\begin{tabular}{lcccccc}
\hline Fish species & $\begin{array}{c}\mathrm{N}^{\circ} \text { of } \\
\text { cohorts }\end{array}$ & $a$ & $b$ & $\begin{array}{c}L_{\infty} \\
(\mathrm{cm})\end{array}$ & $\begin{array}{c}K \\
\left(\text { year }^{-1}\right)\end{array}$ & $\begin{array}{c}t_{0} \\
(\text { year })\end{array}$ \\
\hline S. scrofa & 23 & 0.022 & 2.94 & 55.4 & 0.070 & 0.0 \\
M. surmuletus & 6 & 0.007 & 3.17 & 39.7 & 0.300 & 0.0 \\
S. officinalis & 2 & 0.270 & 2.26 & 62.3 & 0.002 & -0.2 \\
S. porcus & 14 & 0.018 & 3.02 & 34.3 & 0.130 & 0.0 \\
\hline
\end{tabular}

\subsection{Socioeconomics}

Socioeconomic interviews were first used to describe Mediterranean trammel net fleet (using red mullet and cuttlefish nets) as composed by approximately 138 vessels rarely larger than $10 \mathrm{~m}$ length (average $8.55 \mathrm{~m}$ ) and a gross tonnage between 2 to 5 GT usually operated by a single fisher (very often, the owner of the vessel). In the summer months, some vessels operate with two fishers.

Looking into fishing tactics, two main trammel net types are used during the year: Cuttlefish net $(67 \mathrm{~mm})$ is used from January to June in the six harbours where interviews were made $(100 \%$ of the interviews). Red mullet net $(50 \mathrm{~mm})$ is used from July to November by 13 of 27 fisher interviewed (48\%), located in Alcúdia (7/8), Colònia de Sant Jordi (3/6), Palma (1/2) and Porto Colom (2/2). This net was not reported in Pollença (4 interviews) or in Cala Ratjada (4 interviews).

Landings of the four species were not always reported at the same time during the year. Seasonal patterns of their exploitation can be observed (Fig. 7). It shows the annual landings average distribution all along the year: red scorpionfish is mainly caught from April to August (21-25 cm individuals).

Relating this seasonality apparent in the landings statistics with the interviews results, red scorpionfish is caught both with the $67 \mathrm{~mm}$ (larger individuals, 25-30 cm) and the $50 \mathrm{~mm}$ 


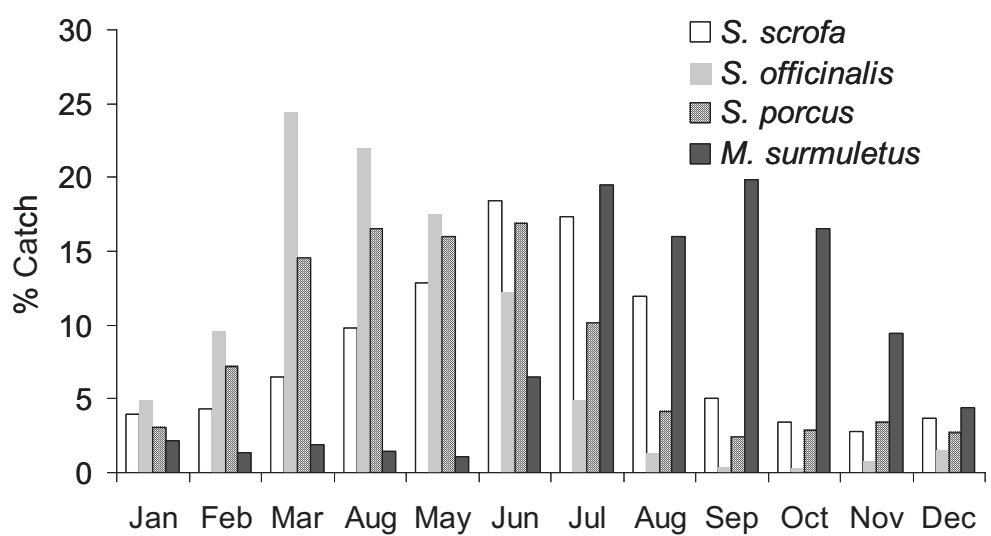

Fig. 7. Monthly distribution of the four species landings (based on official data by the General Fisheries Directorate). Target species seasonal distribution is closely related to the trammel used.

trammel nets (smaller individuals, $21-25 \mathrm{~cm}$ ). Red mullet is mainly targeted from July to November with the $50 \mathrm{~mm}$ net. Cuttlefish (6-15 cm individuals) is mainly landed from March to June with the $67 \mathrm{~mm}$ net. Black scorpionfish is also landed from March to June with the cuttlefish net (16-20 cm individuals).

Non target species of interest for the fishers using cuttlefish $(67 \mathrm{~mm})$ and red mullet nets $(50 \mathrm{~mm})$ are highly priced fish such as common dentex (Dentex dentex), fourspotted megrim (Lepidorhombus boscii), greater amberjack (Seriola dumerili) and seabreams (Sparus sp.).

Trammel netters spend an average of 7-8 working hours at sea and 4.5 working in the harbour. The fuel consumption is not always high enough to apply for public subsidies ( $300 \mathrm{~L}$, $150 €$ per week). The average price of a trammel net including nets, manufacture and lead oscillates from 4000 to $4800 €$ for the allowed trammel net for a boat with one fisher $(2000 \mathrm{~m})$, and most of fishers $(21 / 27)$ buy them in the mainland and build them by themselves.

The average lifespan of a trammel net differs between users. Some repair them every season and may use it for five years. However, 21 from 27 use a new trammel net every 1.53 years. The investments in gear maintenance were not an easy question to answer. Differences arise between fishers working alone on their boats and the ones operating with one more fisher. When it was the case, through a part salary system, a fraction of the total income after selling their product minus fuel costs was removed for vessel maintenance (easier to estimate). When the owner was the only fisher operating, the investments in maintenance were not fixed and neither as easy to estimate. Not all the fishers understood the question in the same way but as a proxy value it can be stated that in average, for all the vessels, maintenance costs must be around $~ 40 \%$ of their total income minus fuel costs. Engine renewal is not a clear question, either, some fishers are using the same engine since 25 years ago and others estimate a 10 -year duration. The current price of the engines used by the Majorca trammel net fleet is $33000 €$ approximately.

The 27 fishers interviewed were asked about their complaints and suggestions about the current management of small scale fisheries in Majorca Island and answers were well related to their geographical location. Fishers in Colònia de Sant Jordi and Pollença significantly complain about recreational fishers (spearfishing) which become strong market competitors. Spearfishers sell their product to local restaurants (illegally) at high price with no commercialization license and affect trammel net fish demand and consequently price. Fishers in Alcúdia were not satisfied with the recently imposed commercialization process. Fishers leave their product and it is sold in the local market with no interaction between fishers and buyers. Fish is sold through an auction sale. According to their complaints, fish middlemen use not very fair tactics, such as that after offering high prices, they claim that the fish is damaged or not in sufficiently fresh condition and obtain lower prices with no re-auction sale. Lastly, fishers from Cala Ratjada find their red mullet nets $(50 \mathrm{~mm})$ damaged by the presence of dolphins and as a consequence, its use is becoming less frequent.

The fishers find the season (related to tourism) as the main factor determining the price of fish, which seems natural as the local demand is significantly increased by restaurants in summer.

Another relevant aspect to highlight is the geographical differences in the social component of the activity. Fishers in some harbours (Palma, Cala Ratjada, Alcúdia) had fishing as their only employment and their situation did not seem as comfortable as it was in other harbours (especially Colònia de Sant Jordi). Many of the fishers interviewed in this port had their own works out of fishing, which was a secondary source of income in family's economy.

The management actions proposed were related to a better application of the current management rules (12/27), control on the recreational fishing $(14 / 27)$ and improvements to increase selling price $(13 / 27)$ and commercialization process (13/27). Marine reserves are not well accepted by a part of the fishing community but especially younger fishers agree with them. In some cases (6/27), the creation of marine reserves is proposed by the fishers.

Fishers expect to get better selling prices if a one day effort reduction was implemented: Nets are all the night in the sea and brought to local market in the morning. On weekends no fishing is allowed from Saturday after $14 \mathrm{~h}$ till Sunday at $12 \mathrm{~h}$. As the Wharf is closed on Monday, the prices of the captures of Monday morning are expected to decrease. Price relation with size, day of the week have also been matter of analysis of the 
market in situ surveys (Reglero and Morales-Nin 2008). Prices and consequently their profits should significantly increase.

The bioeconomic simulation was performed with a two species resource exploited by two gears (or métiers). Red mullet and red scorpion fish are the two species generating higher profits $(632 \mathrm{k} €$, Fig. 1b). The first is caught both with the 67-mm and the 50-mm trammel net from May to August and the second is mainly fished from July to November with the $50 \mathrm{~mm}$ trammel net. The bioeconomic simulation is a two species, two gears, deterministic simulation projected for the next 15 years. The two species initial population and parameters (Table 3) were obtained from the virtual population analysis with VIT software (Lleonart and Salat 1992) including two gears landings in 2005.

The average vessels using the two nets are not exactly the same but similar (Tables 4 and 5), which also happens in other Spanish Mediterranean regions (Garcia-Rodriguez et al. 2006).

The price dynamics used is a constant price model for red scorpionfish and an offer demand function with a base price (A) and a price modification parameter when modifying the offer (linear decrease of price as the offer increases, flexibility, $B$ ) for the red mullet. The market box includes parameters to account for secondary species profits to be accounted in the total revenues (Table 6). First, $\eta$ relates target species landings to secondary and second $p s$, is the average price of secondary species.

The current scenario shows a constant and sustainable situation of the exploitation with revenues around $1.3 \mathrm{k} €$ (not discounted). The management action tested did not aim to solve an overexploitation or rent dissipation problem in the trammel net fishery but to improve fishers' work condition and profits through a hypothetical price increase of their product.

The fifteen year bioeconomic and deterministic simulation shows the effects on total profits of a one day effort reduction in the trammel net fishery occurring the third year (Fig. 8).

The production reduction is the cause of red mullet's price increase, which smoothes the total economic loss (black circles). Out of the offer-demand price formation process, some hypothetical price increases were simulated (white circles, triangles and asterisks). The simulated increase of target and secondary species price $(2 \%, 4 \%$ and $6 \%)$, are not enough to balance the loss of production. It is important to remark that the linear offer-demand function used balances the profits loss more than an induced $2 \%$ price increase in target and secondary species.

After the simulation, the required price change to balance the loss of production was investigated. Figure 9 shows that the price increase needed to balance trammel net fleets profits is at least a $12 \%$ increase in target and secondary species, which does not seem realistic.

\section{Discussion}

Majorca Island's trammel net fishery represents an example of well-developed traditional fisheries, documented since ancient times (Bas 2002) with significant socio-economic and cultural importance. This aspect of artisanal fisheries has also been highlighted by many authors in different regions
Table 3. Species, age, initial number $(N)$, maturity index (mat) and initial fishing mortality of the cuttlefish trammel net $\left(F_{\mathrm{CTN}}\right)$ and red mullet trammel net $\left(F_{\mathrm{RMTN}}\right)$. Natural mortality rate for $S$. scrofa is 0.23 and for $M$. surmuletus 0.43 . Note that a constant recruitment $(R)$ model is used and $R=N_{0}$.

\begin{tabular}{lccccc}
\hline Fish species & Age & $N$ & mat & $F_{\text {CTN }}$ & $F_{\text {RMTN }}$ \\
\hline S. scrofa & 4 & 328537 & 0.00 & 0.00 & 0.00 \\
& 5 & 260516 & 0.00 & 0.01 & 0.01 \\
& 6 & 203796 & 0.00 & 0.01 & 0.02 \\
& 7 & 156520 & 0.01 & 0.02 & 0.02 \\
& 8 & 119313 & 0.02 & 0.04 & 0.01 \\
& 9 & 89889 & 0.05 & 0.04 & 0.02 \\
& 10 & 67312 & 0.12 & 0.05 & 0.03 \\
& 11 & 49529 & 0.27 & 0.05 & 0.02 \\
& 12 & 36551 & 0.50 & 0.05 & 0.01 \\
& 13 & 27300 & 0.73 & 0.06 & 0.01 \\
& 14 & 20467 & 0.88 & 0.05 & 0.02 \\
& 15 & 15330 & 0.95 & 0.06 & 0.02 \\
& 16 & 11213 & 0.98 & 0.09 & 0.02 \\
& 17 & 7980 & 0.99 & 0.09 & 0.03 \\
& 18 & 5631 & 0.99 & 0.07 & 0.04 \\
& 19 & 3996 & 0.99 & 0.06 & 0.01 \\
& 20 & 2959 & 1.00 & 0.04 & 0.00 \\
& 21 & 2259 & 1.00 & 0.04 & 0.05 \\
22 & 1637 & 1.00 & 0.07 & 0.07 \\
& 23 & 1132 & 1.00 & 0.13 & 0.00 \\
& 24 & 789 & 1.00 & 0.09 & 0.00 \\
& 25 & 572 & 1.00 & 0.12 & 0.00 \\
26 & 404 & 1.00 & 0.15 & 0.00 \\
\hline M. surmuletus & 1 & $R=402744$ & 0.00 & 0.00 & 0.00 \\
2 & 261497 & 0.14 & 0.04 & 0.38 \\
& 3 & 111578 & 0.61 & 0.09 & 0.78 \\
4 & 30446 & 0.95 & 0.10 & 0.60 \\
& 5 & 9830 & 1.00 & 0.05 & 0.36 \\
6 & 4257 & 1.00 & 0.01 & 0.09 \\
\hline & & & &
\end{tabular}

Simulation of a 1 Day Effort Reduction with MEFISTO

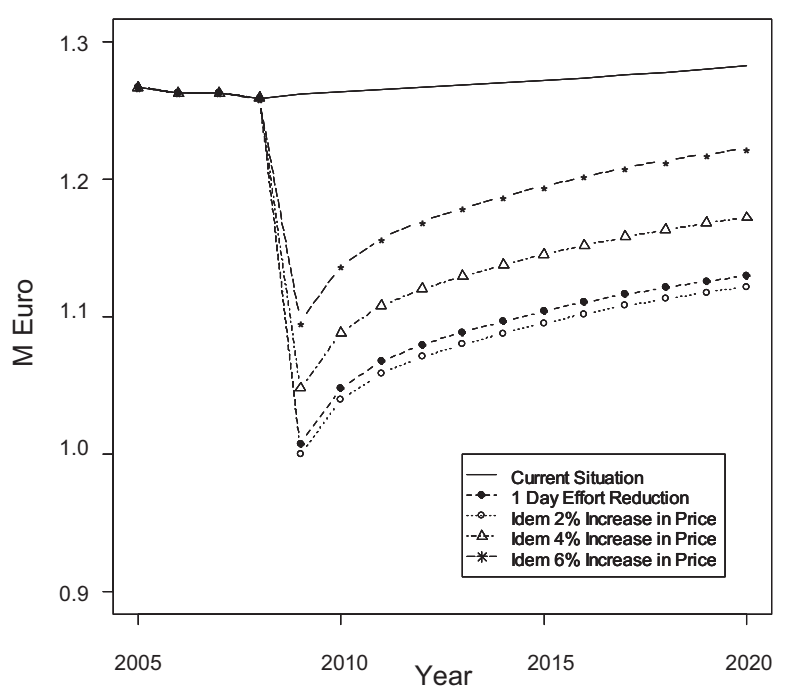

Fig. 8. Simulated profits for the Majorca trammel net fleet including two gears and two target species. The effects of a one day (20\%) effort reduction are displayed in the five trajectories. Note that the effort reduction is located the third year of the simulation. 


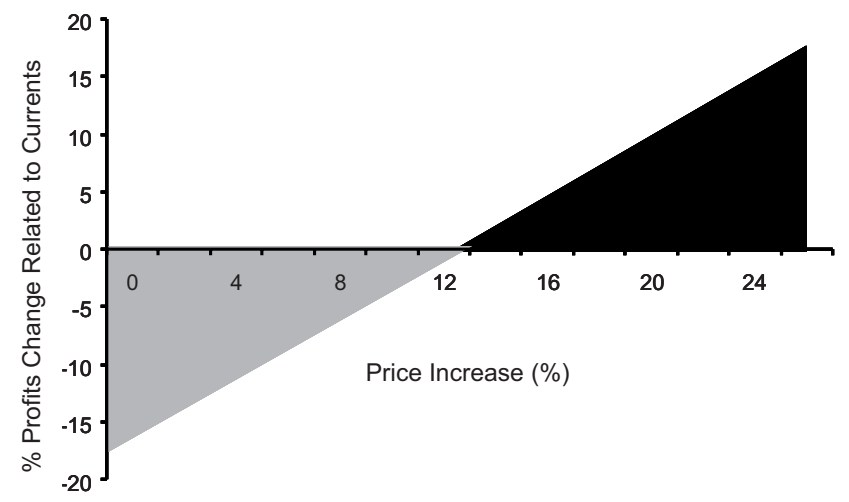

Fig. 9. Simulated economic loss or gain (\%) in a ten year interval for the different expected fish price increases of the trammel net fishery in Majorca Island. The price increase is applied to the target and non target species.

(Martorell and Oliver 1986; Guillou et al. 2002; FAO 2003; Lleonart and Maynou 2003; Maynou et al. 2003; Colloca et al. 2004; Garcia-Rodirguez et al. 2006; Royer et al. 2006; Stergiou et al. 2006; Tzanatos et al. 2006). In common with tropical artisanal fisheries, the "trammel net" fleet is polyvalent and targets many species using a wide variety of fishing gears (e.g. Trammel-nets, longlines, gill nets, dredges) and range of fishing grounds. The gear used and the species targeted are highly seasonal, similar to other European regions (Stergiou et al. 1997; Lleonart and Maynou 2003; Colloca et al. 2004; Garcia-Rodriguez et al. 2006; Tzanatos et al. 2006), driven by local market demand and seasonal catch value. The exploited species are commercialized fresh and arise high market values, especially in the tourism season (summer).

Trammel net does not represent a threat to the sustainability of Majorca Island fishery resources and the management actions proposed by fishers and local managers are more related to improving the communities' socioeconomic situation than to preserve the natural resource. The target species seasonality and selectivity of the inner mesh used and fishing grounds are the key for metier and target species identification as happens in other European regions (Stergiou et al. 2006). Following this, an inner mesh size is chosen to capture species which show significant seasonal variability in a given ground. The outer mesh size was not considered representative in the present work to explain patterns on catch rates, species or season (Stergiou et al. 2006). The target species and mesh sizes identified in the present work are also described in trammel net studies in other areas (Colloca et al. 2004; Stergiou et al. 2006; Tzanatos et al. 2006).

The results of the interviews allowed to characterize an average trammel net fishers in Mediterranean waters for the first time. Although trammel net is not an economically relevant activity, knowing that it employs at least 138 fishers its socioeconomic and cultural relevance is highlighted.

The four target species exploited in Majorca are common to many other Spanish Mediterranean fisheries (Garcia-Rodriguez et al. 2006).

The data and analysis presented here aim to reduce the current lack of quantitative data on Mediterranean artisanal
Table 4. Fleet characteristics. Number of vessels operating with each gear $(N V)$, part to the owner (Part), annual increase of catchability coefficient $(\partial \mathrm{q}$, based on unpublished estimations), number of hours per day $(N H D)$, number of fishing days by year $(N F D)$, commercial tax (\% comm.) and fuel price (Fuel).

\begin{tabular}{lccccccc}
\hline Gear & $N V$ & $\begin{array}{c}\text { Part } \\
(\%)\end{array}$ & $\partial \mathrm{q}$ & $N H D$ & $\begin{array}{c}N F D \\
\text { comm. }\end{array}$ & $\begin{array}{c}\% \\
(€ / \mathrm{L})\end{array}$ & Fuel \\
\hline CTN & 138 & 40 & 0.01 & 7.8 & 120 & 7 & 0.49 \\
RMTN & 98 & 40 & 0.01 & 8 & 100 & 7 & 0.49 \\
\hline
\end{tabular}

Table 5. Average vessel of the CTN and RMTN fleets. Capital $(K)$ (euros), gross tonnage (GT), fuel consumption (Fuel) and annual costs (annual C).

\begin{tabular}{lcccc}
\hline Gear & $K(€)$ & $\begin{array}{c}G T \\
(\text { ton })\end{array}$ & $\begin{array}{c}\text { Fuel } \\
(\mathrm{L} / \text { day })\end{array}$ & $\begin{array}{c}\text { Annual C } \\
(€)\end{array}$ \\
\hline CTN & 148858 & 2.94 & 38.9 & 5423 \\
RMTN & 149736 & 2.83 & 40.8 & 4493 \\
\hline
\end{tabular}

Table 6. Price parameters ( $A=$ base price and $B=$ price flexibility $)$ for the two target species (red scorpionfish and red mullet); secondary species catch for each to target species unit ( $\eta$, fleet related) and secondary species average price with the two gears ( $p s$, fleet related), (based on General Fisheries Directorate daily selling records, 20022006).

\begin{tabular}{llcccc}
\hline Gear & Target species & $\begin{array}{c}A \\
(€ / \mathrm{kg})\end{array}$ & $B$ & $\begin{array}{c}\eta \text { (secon } \\
\text { /target) }\end{array}$ & $\begin{array}{c}p s \\
(€ / \mathrm{kg})\end{array}$ \\
\hline CTN & S. scrofa & 31.65 & 0.0 & 16.39 & 22 \\
CTN & M. surmuletus & 15.09 & 0.0003 & - & - \\
RMTN & S. scrofa & 31.65 & 0.0 & - & - \\
RMTN & M. surmuletus & 15.09 & 0.0003 & 4.53 & 22 \\
\hline
\end{tabular}

fisheries (Colloca et al. 2004). Uncertainty on fisheries assessments represents a handicap for decision making and management of Mediterranean fisheries (Lleonart and Maynou 2003).

The manner to obtain this is the point where there is a controversy. Some fishers reject the current selling process where they are not involved in the selling process. Currently, fishers' production is sold out by auction in the wharf and they perceive a resulting percentage of this sale. Factors affecting price are delivery conditions, day of the week, season and size (Reglero and Morales-Nin 2008). It is suggested that any management should be directed to control the factors affecting price formation.

The bioeconomic simulation allows the advice about an effort reduction management action, not estimated to provide the community with higher profits. The price increase predicted by the fishers that proposed this management action does not seem to be enough to balance the economic loss derived by the predicted decrease in production. The recorded in situ market prices to red scorpionfish $(\sim 30 € / \mathrm{kg})$ and red mullet $(\sim 8 € / \mathrm{kg})$ should be increased more than their $12 \%$ to compensate the lower landings after the one day activity reduction.

However, the model used for the simulations, MEFISTO was performed with some limitations. The price dynamics based on offer-demand functions do not seem to explain all the observed price variability, mainly relying on the size of the individuals (Garcia-Rodriguez et al. 2006; Reglero and Morales-Nin 2008). 
Effort reductions in a fishery at stable levels of maximum sustainable yield might have lead the fishery to a maximum economic yield level (Gordon 1954). In the presented simulation with an age structured model, MEFISTO (Lleonart et al. 2003), the exploitation reduces significantly (10-15\%) its total economic yield.

The authors want to address the need of future quantitative studies for a better understanding of small scale fisheries socioeconomics.

Acknowledgements. This study was funded by the Commission of the European Communities, specific RTD programme "Specific Support to Policies", SSP-2004-22745 "Probabilistic assessment, management and advice model for fishery management in the case of poor data availability" (POORFISH). We thank Patricia Reglero (IEO) for her collaboration.

\section{References}

Bas C., 2002, The Mediterranean Sea: Living resources and exploitation. Zaragoza.CIHEAM-IAMZ / FAO-COPEMED.

Colloca F., Crespi V., Cerasi S., Coppola S.R., 2004, Structure and evolution of the artisanal fishery in a southern Italian coastal area. Fish. Res. 69, 359-369.

Dunn M.R., 1999, Aspects of the stock dynamics and exploitation of cutlefish, Sepia officinalis (Linnaeus, 1758), in the English Channel. Fish. Res. 40, 277-293.

FAO, 2003, Strategies for increasing the sustainable contribution of small-scale fisheries to food security and poverty alleviation. FAO COFI/2003/9, 1-14.

Forsythe J., Lee P., Walsh L., Clark,T., 2002, The effects of crowding on growth of the European cuttlefish, Sepia officinalis Linnaeus, 1758 reared at two temperatures. J. Exp. Mar. Biol. Ecol. 269, 173-185.

Iglesias M., Massutí E., Reñones O., Morales-Nin B., 1995, Three small-scale fisheries based on the island of Majorca (NW Mediterranean). Monografies Bolleti Societat Historia Natural Balears, 37, 35-58.

Garcia-Rodriguez, M., Fernandez, A.M., Esteban, A., 2006, Characterisation, analysis and catch rates of the small-scale fisheries of the Alicante Gulf (SE Spain) over a 10 years time series. Fish. Res. 77, 226-238.

Gordon H.S., 1954, The economic theory of a common-property resource: the fishery. J. Polit. Econ. 62, 124-142.

Lleonart J., Maynou F., 2003, Fish stock assessments in the Mediterranean: state of the art. Sci. Mar. 67, 37-49.

Lleonart J., Maynou F., Recasens L., Franquesa R., 2003, A bioeconomic model for Mediterranean fisheries, the hake off Catalonia (western Mediterranean) as a case study. Sci. Mar. 67, 337-351.
Maynou F., Demestre M., Sánchez P., 2003, Analysis of catch per unit of effort by multivariate analysis and generalised linear models for deep-water crustacean fisheries off Barcelona (NW Mediterranean). Fish. Res. 65, 257-269.

Merino G., Karlou-Riga C., Anastopoulou I., Maynou F., Lleonart J., 2007, Bioeconomic simulation analysis of hake and red mullet fisheries in the Gulf of Saronikos (Greece). Sci. Mar. 71, 525535.

Merino G., Maynou F., Garcia-Olivares A., 2007, A new bioeconomic simulation tool for small scale fisheries based on game theory: GAMEFISTO model. Aquat. Living Resour. 20, 223-230.

Morales-Nin, B., 1991. Parámetros biológicos de Mullus surmuletus (L. 1758) en Mallorca. Bol. Inst. Esp. Oceanogr. 7, 139-147.

Morey G., Moranta J., Massutí E., Grau A., Linde M., Riera F., Morales-Nin B., 2003, Weight-length relationships of litoral to lower slope fishes from the Western Mediterranean. Fish. Res. 62, 89-96.

Punt A.E., 1992, Selecting management methodologies for marine resources with an illustration for South African hake. S. Afr. J. Mar. Sci. 12, 943-958.

Reglero P., Moreales-Nin B., 2008, Relationship between first sale price, body size and total catch of trammelnet target species in Majorca (NW Mediterranean). Fish. Res. In press.

Royer J., Pierce G.J., Foucher E., Robin J.P., 2006, The English Channel stock of Sepia officinalis: Modelling variablity in abundance and impact of fishery. Fish. Res. 78, 96-106.

Sanchez P., Demestre M., Ramon M., Kaiser M.J., 2000, The impact of otter trawling on mud communities in the northwestern Mediterranean. ICES J. Mar. Sci. 57, 1352-1358.

Schaefer M.B., 1954, Some aspects of the dynamics of populations important to the management of commercial marine fisheries. Bull. IATTC 2, 247-285.

Schnute J., 1985, A general theory for analysis of catch and effort data. Can. J. Fish. Aquat. Sci. 42, 414-429.

Stergiou K.I., Christou E.D., Petrakis G., 1997, Modelling and forecasting monthly fisheries catches: comparison of regression, univariate and multivariate time series methods. Fish. Res. 29, 5595.

Stergiou K.I., Moutopoulos D.K., Soriguer M.C., Puente E., Lino P.G., Zabala C., Monteiro P., Errazkin L.U., Erzini K., 2006, Trammel net catch species composition, catch rates and métiers in southern European waters: A multivariate approach. Fish. Res. $79,170-182$.

Tzanatos E., Somarakis S., Tserpes G., Koutsikopoulos C., 2006, Identifying and classifying small-scale fisheries métiers in the Mediterranean: A case study in the Patraikos Gulf, Greece. Fish. Res. 81, 158-168.

Ulrich C., Le Gallic B., Dunn M.R., Gascuel D., 2002, A multispecies, multi-fleet bioeconomic simulation model for the English Channel artisanal fisheries. Fish. Res. 58, 379-401. 